\title{
CREATIVITY OF TRAINEE TECHNOLOGY TEACHERS OF THE BALTIC COUNTRIES AS READINESS TO EDUCATE LEARNERS MEETING THE NEEDS OF THE LABOR MARKET OF THE BEGINNING OF THE $21^{\text {ST }}$ CENTURY
}

\author{
Ilona Valantinaitė \\ Vilnius Gediminas Technical University, Lithuania
}

\begin{abstract}
The paper analyzes the requirements for the labor market at the beginning of the $21^{\text {st }}$ century, and overviews the novelties of employee assessment and selection which make a claim on the school and higher education, in particular teacher training. The priority for a creative society is a creative participant in the labor market. The needs of the multicultural market can be met by people who were brought up in a stable culture and are able to offer uniqueness and novelty, therefore, the paper focuses on the Baltic countries which are similar in their historical, political and geographical situation. The article analyzes the creativity of the trainee Technology teachers in their final years of study in the Baltic countries. Creativity breeds creativity, hence, the creativity of trainee teachers is analyzed as their readiness to educate learners who would meet the requirements of the labor market of the beginning of the $21^{\text {st }}$ century. The activity of a creative person is relevant in diverse contexts from the school to the employer. Technology teachers were selected due to the particularity of their subject. In classes of home economics different school subjects are applied practically, thus the creativity of Technology teachers is becoming exclusive in the context of preparing learners for life. Relating the literature review and the data of a qualitative analysis, it can be anticipated that a creative teacher of Technologies in the Baltic countries can be an indicator of an attractive and successful school of the beginning of the $21^{\text {st }}$ century.
\end{abstract}

Keywords: Technologies (home economics), Technology teacher, creativity, expression of creativity.

\section{Introduction}

In the context of the transformational process when the information society is turning into a creative one, every person's creativity is becoming a goal to be attained. Most strategic EU documents on education emphasize the development of the young generation's creativity. Personal creativity is also becoming a matter of interest to employers (Jieun et al. 2010; Abreu, 2012; Gong et al., 2012; Rego et al., 2014). There appear discussions on the possible ways to stimulate the creativity of employees of the beginning of the $21^{\text {st }}$ century. More and more frequently companies make use of differentiated assignments, create favorable conditions for leadership, use promotional programmes, etc. (Jieun et al. 2010). An active organization in any market aims to create a suitable environment for the development of employees' creativity and knowledge, and thus seeks to win the competitive struggle (Girdauskiené, 2013). Moreover, researchers investigating the relation between the human capitaland the economic growth in twenty seven countries of the European Union, distinguish 
the significance of personal creativity for the regional development in different spheres (Marrocu, Paci, 2013).

The results of scientific research show that creative employees are proactive and more inclined to share information. Undoubtedly, one of the most expensive items nowadays is information. People who manage information also manage finances, time, human resources and other elements which are important for the development of any company. Benevolent and timely sharing of information creates a safe, trustworthy atmosphere in the workplace and simultaneously stimulates the creativity of the other employees. In other words, creativity breeds creativity that aims at attaining the goals of the company in a psychologically safe and friendly environment (Gong et al., 2012). Creative personalities stimulate the growth of economy (Abreu, 2012), while a positive emotional atmosphere enhances the work efficiency in the service sector. It is estimated that the positive emotional atmosphere which also stimulates creativity can become one of the most significant indicators of competition in retail trade at the beginning of the $21^{\text {st }}$ century (Rego et al., 2014). In the context of competitive organizations and promising businesses the significance of the labor market participants' creativity has become a priority issue (Jieun et al. 2010).

With the growing requirements of the labor market, the process of employee selection is also becoming more complicated. The leading organizations increasingly tend to rely on employee assessment centers that apply the methodology of games, which sometimes last as long as several hours, in the process of candidate selection. Game-like situations help to reveal a person's real attitude to work, professional knowledge, and, most importantly, their personal creativity which can be implemented and developed for the benefit of the company. The $21^{\text {st }}$ century methodology applied to select the participants of the labor market enables the selection of the best candidates for every employer. Such a process of selection requires time to be implemented (Girdauskienè, 2013). In the present day context the development of personal creativity is conceived as a complex long-term process that starts at school and lasts for the lifetime.

The school is a place where personalities develop and mature; they learn to cognize and express themselves, broaden their outlook, acquire knowledge, develop their social skills and participate in other teaching / learning processes. The main goal of school, as an institution, is the preparation of every learner for real life on the basis of their individual abilities (Law on Education of the Republic of Lithuania, 2011). Every learner of today is a tomorrow's participant of the labor market, a creator of the economic and social welfare. Dalin et al. (1999) claim that the process of education, when teachers and students cooperate within the limits of the same school, is the best way to get ready for diverse roles in the family, at a workplace or at a leisure time. In other words, the official teaching/ learning process is made of the official educational 
programmes of the country and "the secret educational programme" which teaches most skills necessary for real life. The latter programme is implemented by participating in the school's social life: by clarifying and analyzing different needs, by formulating the goals of any activity, by designing plans, joining experimental projects, by organizing work groups and taking part in their activity, by making individual discoveries of values, pursuing responsible and creative activity, and in any other typical learning environment. It has to be noted that it is namely the teacher who creates conditions, sets up the necessary environment for learner development at school - from lessons to periods of recess, information boards, informal education and other "secret educational programmes" (Dalin et al., 1999; Scott, 2007; Arias, Scafildi, 2009; Haifeng, 2010; Miller, Imrie, Cox, 2014).

It has to be emphasized that the interrelation of the official educational programmes and "the secret educational programmes" is best manifested in the lessons of technological education (home economics): in Lithuania technologijos, in Latvia - majturiba, in Estonia - kodundus) where the knowledge of all the other subjects is implemented in practical, most frequently, household, daily activities by recognizing and fostering value-related attitudes. Technological education is implemented by means of project methodology which efficiently adds to the learners' preparation for real life and the constantly changing labor market (General Programmes of Primary and Basic Education, 2008). A professional teacher of Technologies is good at motivational techniques, is aware of the dynamics of different groups of learners and can successfully manage the overall process of education developing the learner's creativity at the same time. It has to be noted that it is namely the lessons of Technologies that pay exceptional attention to the expression and development of creativity in relation to the productive activity which finishes with a tangible result. The development of learners' creativity requires a creative teacher of Technologies - a personality that is looked up to by others (Statauskiene, 2003, 2005; Žygaitienè et al., 2014).

A school leaver of the $21^{\text {st }}$ century, who wants to comprehend the market formed by the laws of economics as well as the labor market, will not limit himself to the theoretical knowledge. The long-term process of personal development is becoming especially relevant. The success of finding one's place in life is more and more dependent on personal qualities, creativity and imagination (Morgan, 2004). The more complex and demanding labor market is also putting higher demands on the school (Girdauskiene, 2013) and higher education, in particular teacher training, aiming to enhance the results of trainee teachers' ideas and activity (Hong et al., 2008). Hence, higher education is challenged to rediscover liberal values based on humanism and aim at a successful implementation of the study goals (Morgan, 2004; Haifeng, 2010; Miller, Imrie, Cox, 2014). Haifeng (2010) claims that the university is the only factor affecting the mobility of talented people and the creation of new 
workplaces. Moreover, it is expected that the teacher of the $21^{\text {st }}$ century will also be a manager of change: a person who will answer the needs of his learners, their parents / guardians, the school and the developing labor market, will meet the needs of the society by creating something new, offering untested solutions, developing the learners' abilities which will be relevant in the future. All of this challenges the process of teacher training (Scott, 2007), the main focus of which should be the individual creativity of trainee teachers. Only a creative personality can engage in learning even in routine activity while learning individually or in cooperation, working consistently, responsibly and diligently, and at the same time pragmatically and / or unpredictably. Only a creatively free and strong person can flexibly adapt to the ongoing change, acknowledge his ignorance with dignity and admit that he might never get only one accurate answer (Dalin et al., 1999; Hong et al., 2008; Urhahne, 2011).

The topicality of the significance of teacher training is also supported by research results demonstrating that quality teacher training has a direct influence on the results of learners' achievements (Arias, Scafildi, 2009). A comprehensive analysis of the educational process reveals that it is often the case that teachers have insufficient professional competence, feel unprepared for their work in the classroom (Scott, 2007), have difficulty assessing the learners' creativity (Urhahne, 2011). Researchers claim that teacher competence is mostly related to the skills of risk management and initiative (Hong et al., 2008), which result from personal creativity. Bradley (2011) believes that creativity is best revealed in the communities possessing a strong cultural background. In the global world cultural stability is considered to be an anti-creative environment; nevertheless, the scholar argues that the cosmopolitan world needs people developed in a stable and free country which is rich in unique art and culture. Only such people meet the requirements of a cosmopolitan market to be unique and innovative.

The peculiar demands of the $21^{\text {st }}$ century labor market are directly targeted at a Technology teacher who will educate creative participants of the labor market of tomorrow, who comprises a synthesis of national traditions and latest inventions, creativity and production, freedom of choice by preserving identity as well as freedom to search, take risks and remain a calm and attractive person who is looked up to by others. The present research focuses on historically, politically and geographically similar Baltic countries. The aforementioned research data make it possible to formulate the problem of the study in the following way: what is the creativity of trainee teachers of Technologies in their final years of studies who will educate learners for the labor market at the beginning of the $21^{\text {st }}$ century in the Baltic States?

The object of the paper is the creative expression of trainee Technology teachers in their final years of study in the Baltic countries. 
The goal is to reveal the creative expression of the Baltic trainee Technology teachers in their final years of study as a precondition for their readiness to educate the learners of the $21^{\text {st }}$ century.

The objectives:

- To investigate the creative expression of the Baltic trainee Technology teachers in their final years of study.

- To reveal the creativity of the Baltic trainee Technology teachers in their final years of study as a precondition for their readiness to educate the learners of the $21^{\text {st }}$ century.

The research methods: scientific literature and document review, qualitative research based on Torrance's recommendations.

\section{Methodology}

In 2014 in the universities of Lithuania, Latvia and Estonia there was a qualitative research conducted. The Baltic States are similar to each other in their historical, political and geographical situation. The research encompassed the trainee teachers of home economics in their final years of study: 5 students from Lithuania, 7 students from Latvia and 7 students from Estonia. The informants were given questionnaires for diagnosing their personal creativity. The creativity questionnaires were prepared on the basis of Torrance's (1988) recommendations and the Lithuanian General Education Programmes (2008) for grades 5 to 12 . The questionnaire consisted of two parts: the verbal and nonverbal one (Fig. 1).

Both the verbal and non-verbal parts of the questionnaire include four tasks. The tasks in the verbal part were composed on the basis of the curriculum of home economics which comprises four spheres: nutrition, textile, constructive materials and electronics. For the non-verbal tasks on creativity every informant received a box of twelve colored pencils and a pencil sharpener. The choice of colors and their application were not predetermined. The respondents had a limited period of time to complete both the verbal and nonverbal assignments, and the length of time depended on the type and complexity of tasks (Fig. 1).

\section{The characteristics of the informants}

The sample of a qualitative research is purposive and typically convenient (Patton, 2002). The nineteen informants who participated in the research were of different ages: from 21 to 41 (Table 1). The students in Estonia were older than those in Latvia and Lithuania. The students from Latvia had the highest average grades for their study achievements (8.99). The studies of Technology Education in the Baltic universities were chosen by people of Estonian, Latvian, Lithuanian, Russian and Polish nationalities (Table 1). 


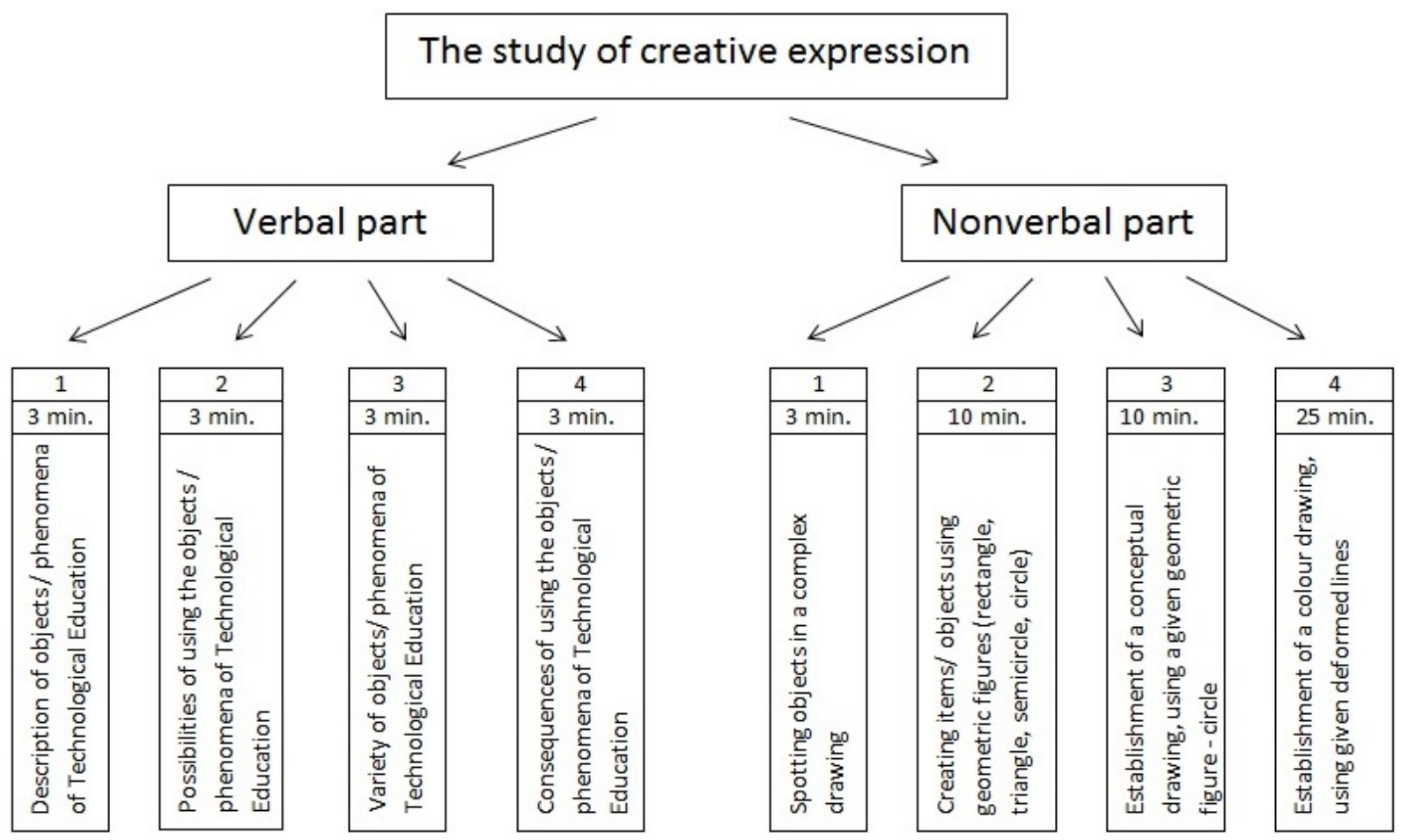

Figure 1. The composition of the questionnaire for analyzing creative expression based on Torrance's (1988) recommendations and the Lithuanian General Education Programmes for Technologies (2008) for grades 5-12

Table 1. Educational and Demographic Characteristics of the Qualitative Research Participants

\begin{tabular}{|l|l|l|l|l|l|l|l|l|l|}
\hline \multirow{2}{*}{ No } & Lithuania & Nationality & $\begin{array}{l}\text { Average } \\
\text { grade of } \\
\text { the last } \\
\text { term }\end{array}$ & Age & Nationality & $\begin{array}{l}\text { Average } \\
\text { grade of } \\
\text { the last } \\
\text { term }\end{array}$ & Age & Nationality & $\begin{array}{l}\text { Average } \\
\text { grade of } \\
\text { the last } \\
\text { term }\end{array}$ \\
\hline 1 & Russian & 9,07 & 22 & Latvian & 8,9 & 22 & Estonian & 7,6 & 32 \\
\hline 2 & Polish & 8,0 & 21 & Latvian & 8,4 & 22 & Estonian & 7,6 & 29 \\
\hline 3 & Lithuanian & 7,0 & 22 & Latvian & 9,4 & 22 & Estonian & 8,4 & 22 \\
\hline 4 & Lithuanian & 8,0 & 22 & Latvian & 9,3 & 21 & Estonian & 9,0 & 27 \\
\hline 5 & Polish & 9,2 & 22 & Latvian & 9,0 & 21 & Estonian & 8,0 & 41 \\
\hline 6 & & & & Latvian & 9,0 & 22 & Estonian & 8,02 & 29 \\
\hline 7 & & & & Russian & 8,9 & 22 & Estonian & 9,0 & 29 \\
\hline
\end{tabular}

\section{Results and discussion}

The creative expression of Lithuanian trainee Technology teachers in their final years of study. The average score of non-verbal creative expression of Lithuanian trainee Technology teachers in their final years of study (269.9) is higher than the average score for the verbal creative expression (252.6) only by 7 percent (Table 2 ). 
Table 2. The scores of creative expression of Lithuanian trainee Technology teachers in their final years of study

\begin{tabular}{|c|c|c|c|c|c|c|c|c|c|c|c|}
\hline \multirow{2}{*}{$\begin{array}{l}\text { Infor- } \\
\text { mant }\end{array}$} & \multicolumn{2}{|c|}{ FLUENCY } & \multicolumn{2}{|c|}{ FLEXIBILITY } & \multicolumn{2}{|c|}{ ORIGINALITY } & \multicolumn{2}{|c|}{$\begin{array}{c}\text { ELABORA- } \\
\text { TION }\end{array}$} & \multicolumn{2}{|c|}{ CREATIVITY } & \multirow{2}{*}{$\begin{array}{l}\text { Ave- } \\
\text { rage } \\
\text { grade }\end{array}$} \\
\hline & $\begin{array}{l}\text { Ver- } \\
\text { bal }\end{array}$ & $\begin{array}{l}\text { Non- } \\
\text { verbal }\end{array}$ & $\begin{array}{l}\text { Ver- } \\
\text { bal }\end{array}$ & $\begin{array}{c}\text { Non- } \\
\text { verbal }\end{array}$ & Verbal & $\begin{array}{c}\text { Non- } \\
\text { verbal }\end{array}$ & $\begin{array}{l}\text { Ver- } \\
\text { bal }\end{array}$ & $\begin{array}{l}\text { Non- } \\
\text { verbal }\end{array}$ & Verbal & $\begin{array}{l}\text { Non- } \\
\text { verbal }\end{array}$ & \\
\hline \multirow{2}{*}{1} & \multicolumn{2}{|l|}{71.1} & \multicolumn{2}{|l|}{132} & \multicolumn{2}{|l|}{212} & \multicolumn{2}{|l|}{21} & \multicolumn{2}{|l|}{436.1} & \multirow{2}{*}{9.1} \\
\hline & 31 & 40.1 & 48 & 84 & 110 & 102 & - & 21 & 189 & 247.1 & \\
\hline \multirow{2}{*}{2} & \multicolumn{2}{|c|}{82.4} & \multicolumn{2}{|l|}{140} & \multicolumn{2}{|l|}{252} & \multicolumn{2}{|l|}{18} & \multicolumn{2}{|l|}{492.4} & \multirow{2}{*}{8.0} \\
\hline & 42 & 40.4 & 57 & 83 & 170 & 82 & - & 18 & 269 & 223.4 & \\
\hline \multirow{2}{*}{3} & \multicolumn{2}{|c|}{83.6} & \multicolumn{2}{|l|}{153} & \multicolumn{2}{|l|}{312} & \multicolumn{2}{|l|}{26} & \multicolumn{2}{|l|}{574.6} & \multirow{2}{*}{7.0} \\
\hline & 45 & 38.6 & 63 & 90 & 175 & 137 & - & 26 & 283 & 291.6 & \\
\hline \multirow{2}{*}{4} & \multicolumn{2}{|l|}{92.2} & \multicolumn{2}{|l|}{173} & \multicolumn{2}{|l|}{272} & \multicolumn{2}{|l|}{22} & \multicolumn{2}{|l|}{559.2} & \multirow{2}{*}{8.0} \\
\hline & 40 & 52.2 & 63 & 110 & 140 & 132 & - & 22 & 243 & 316.2 & \\
\hline 5 & \multicolumn{2}{|c|}{88.1} & 146 & & 294 & & 22 & & 550.1 & & \\
\hline 5 & 44 & 44.1 & 75 & 71 & 160 & 134 & - & 22 & 279 & 271.1 & 2 \\
\hline Ave- & 83.5 & & 148.8 & & 268.4 & & 21.8 & & 522.5 & & 8 \\
\hline rage & 40.4 & 43.1 & 61.2 & 87.6 & 151 & 117.4 & - & 21.8 & 252.6 & 269.9 & 8.2 \\
\hline
\end{tabular}

The informant possessing the highest average grade (9.2) for academic achievements in the group of Lithuanian informants (informant No. 5) distinguishes himself only by exceptional creative flexibility: his verbal creative flexibility is the highest in the group (75), while his non-verbal creative flexibility is the lowest in the group (71). Whereas the informant possessing the lowest average grade (7.0) for academic achievements (informant No. 3) distinguishes himself by the highest scores of general creativity (574.6) and verbal creativity (283) as well as the highest scores in the group for verbal and non-verbal creative originality (175 and 137 respectively), creative elaboration (26) and creative fluency (45), and the lowest score in the group for creative fluency (38.6). Nevertheless, there were no tendentious relations between the creative expression of the Lithuanian informants and their average grades for academic achievements established. Only creative fluency and creative flexibility could be distinguished in the group since their verbal form is better expressed, nevertheless, the Lithuanian informants demonstrated a better revealed non-verbal creativity (Table 2).

The analysis of the qualitative research data shows that the Lithuanian informants, irrespective of their average grades, possess all the target features of creative expression - creative fluency, flexibility, originality and elaboration. Even though non-verbal creativity was better revealed in the group, there was no significant difference between verbal and non-verbal creativity distinguished.

The creative expression of Latvian trainee Technology teachers in their final years of study. The Latvian trainee Technology teachers in the final years of study demonstrated a balanced expression of both verbal and non-verbal creativity (244.57 and 247.83 respectively) (Table 3 ). 
SOCIETY. INTEGRATION. EDUCATION. Volume I

Table 3. The scores of creative expression of Latvian trainee Technology teachers in the final years of study

\begin{tabular}{|c|c|c|c|c|c|c|c|c|c|c|c|}
\hline \multirow{2}{*}{$\begin{array}{l}\text { Infor- } \\
\text { mant }\end{array}$} & \multicolumn{2}{|c|}{ FLUENCY } & \multicolumn{2}{|c|}{ FLEXIBILITY } & \multicolumn{2}{|c|}{ ORIGINALITY } & \multicolumn{2}{|c|}{$\begin{array}{l}\text { ELABORA- } \\
\text { TION }\end{array}$} & \multicolumn{2}{|c|}{ CREATIVITY } & \multirow{2}{*}{$\begin{array}{l}\text { Avera- } \\
\text { ge } \\
\text { grade }\end{array}$} \\
\hline & $\begin{array}{l}\text { Ver- } \\
\text { bal }\end{array}$ & \begin{tabular}{|c|} 
Non- \\
verbal
\end{tabular} & $\begin{array}{l}\text { Ver- } \\
\text { bal }\end{array}$ & \begin{tabular}{|c|} 
Non- \\
verbal
\end{tabular} & Verbal & \begin{tabular}{|c|} 
Non- \\
verbal
\end{tabular} & $\begin{array}{l}\text { Ver- } \\
\text { bal }\end{array}$ & \begin{tabular}{|c|} 
Non- \\
verbal
\end{tabular} & Verbal & \begin{tabular}{|c|} 
Non- \\
verbal
\end{tabular} & \\
\hline \multirow{2}{*}{1} & \multicolumn{2}{|l|}{85.6} & \multicolumn{2}{|l|}{132} & \multicolumn{2}{|l|}{146} & \multicolumn{2}{|l|}{17} & \multicolumn{2}{|l|}{363.6} & \multirow{2}{*}{8.4} \\
\hline & 39 & 46.6 & 54 & 78 & 70 & 76 & - & 17 & 163 & 200.6 & \\
\hline \multirow{2}{*}{2} & \multicolumn{2}{|l|}{82.3} & \multicolumn{2}{|l|}{145} & \multicolumn{2}{|l|}{211} & \multicolumn{2}{|l|}{12} & \multicolumn{2}{|l|}{438.3} & \multirow{2}{*}{9.4} \\
\hline & 38 & 44.3 & 63 & 82 & 110 & 101 & - & 12 & 211 & 227.3 & \\
\hline \multirow{2}{*}{3} & \multicolumn{2}{|l|}{91.6} & \multicolumn{2}{|l|}{146} & \multicolumn{2}{|l|}{206} & \multicolumn{2}{|l|}{22} & \multicolumn{2}{|l|}{443.6} & \multirow{2}{*}{9.3} \\
\hline & 40 & 51.6 & 57 & 89 & 120 & 86 & - & 22 & 217 & 226.6 & \\
\hline \multirow{2}{*}{4} & \multicolumn{2}{|l|}{86.2} & \multicolumn{2}{|l|}{136} & \multicolumn{2}{|l|}{265} & \multicolumn{2}{|l|}{13} & \multicolumn{2}{|l|}{487.2} & $=90$ \\
\hline & 30 & 56.2 & 48 & 88 & 140 & 125 & - & 13 & 218 & 269.2 & 9.0 \\
\hline 5 & 82.7 & & 133 & & 226 & & 19 & & 441.7 & & \\
\hline J & 26 & 56.7 & 51 & 82 & 90 & 136 & - & 19 & 167 & 274.7 & 9.1 \\
\hline 6 & 110.8 & & 183 & & 449 & & 21 & & 742.8 & & \\
\hline 0 & 74 & 36.8 & 84 & 99 & 355 & 94 & - & 21 & 513 & 229.8 & 9 \\
\hline & 97.6 & & 157 & & 275 & & 23 & & 529.6 & & \\
\hline 1 & 41 & 56.6 & 57 & 100 & 125 & 150 & - & 23 & 223 & 306.6 & 8.9 \\
\hline Ave- & 90.97 & & 147.43 & & 254 & & 18.14 & & 492.4 & & 80 \\
\hline rage & 41.14 & 49.83 & 59.14 & 88.29 & 144.29 & 109,71 & - & 18.14 & 244.57 & 247.83 & 5.9 \\
\hline
\end{tabular}

The informant possessing the highest average grade for academic achievements (9.4) in the Latvian group (informant No. 2) distinguished himself by the lowest creative fluency in the group (82.3). No other idiosyncrasies were observed. The informant possessing the lowest average grade

(8.4) in the group (informant No. 1) distinguished himself by the lowest scores for verbal and non-verbal creative originality (70 and 76 respectively), non-verbal flexibility (78), general verbal and non-verbal creativity (163 and 200.6 respectively) in the group. The Latvian group of informants demonstrated an exceptional expression of creative fluency (Table 3). The informant (informant No. 5) who distinguished himself by the lowest score for verbal fluency (26) in the group also stood out from the rest by the highest non-verbal creative fluency (56.7). Whereas the informant (informant No. 6) possessing the highest scores for verbal creative fluency in the group (74) distinguished himself by the lowest non-verbal creative fluency (36.8).

The analysis of the qualitative research data revealed no significant relation between the academic achievements of the Latvian informants and their scores for creative expression. Nonetheless, it has to be noted that the Latvian trainee Technology teachers in the final years of study demonstrated all the target features of verbal and non-verbal creativity (Table 3).

The creative expression of Estonian trainee Technology teachers in their final years of study. 
Table 4. The scores of creative expression of Estonian trainee Technology teachers in the final years of study

\begin{tabular}{|c|c|c|c|c|c|c|c|c|c|c|c|}
\hline \multirow{2}{*}{$\begin{array}{l}\text { Infor- } \\
\text { mant }\end{array}$} & \multicolumn{2}{|c|}{ FLUENCY } & \multicolumn{2}{|c|}{ FLEXIBILITY } & \multicolumn{2}{|c|}{ ORIGINALITY } & \multicolumn{2}{|c|}{$\begin{array}{l}\text { ELABORA- } \\
\text { TION }\end{array}$} & \multicolumn{2}{|c|}{ CREATIVITY } & \multirow{2}{*}{$\begin{array}{l}\text { Average } \\
\text { grade }\end{array}$} \\
\hline & $\begin{array}{l}\text { Ver- } \\
\text { bal }\end{array}$ & \begin{tabular}{|l|} 
Non- \\
verbal
\end{tabular} & $\begin{array}{l}\text { Ver- } \\
\text { bal }\end{array}$ & $\begin{array}{l}\text { Non- } \\
\text { verbal }\end{array}$ & Verbal & $\begin{array}{l}\text { Non- } \\
\text { verbal }\end{array}$ & $\begin{array}{l}\text { Ver- } \\
\text { bal }\end{array}$ & $\begin{array}{l}\text { Non- } \\
\text { verbal }\end{array}$ & Verbal & $\begin{array}{l}\text { Non- } \\
\text { verbal }\end{array}$ & \\
\hline \multirow{2}{*}{1} & \multicolumn{2}{|c|}{100.8} & \multicolumn{2}{|l|}{167} & \multicolumn{2}{|l|}{329} & \multicolumn{2}{|l|}{24} & \multicolumn{2}{|l|}{596.8} & \multirow{2}{*}{7.6} \\
\hline & 50 & 50.8 & 66 & 101 & 200 & 129 & - & 24 & 316 & 280.8 & \\
\hline \multirow{2}{*}{2} & \multicolumn{2}{|c|}{103.8} & \multicolumn{2}{|l|}{157} & \multicolumn{2}{|l|}{336} & \multicolumn{2}{|l|}{25} & \multicolumn{2}{|l|}{596.8} & \multirow{2}{*}{7.6} \\
\hline & 41 & 62.8 & 66 & 91 & 170 & 166 & - & 25 & 277 & 319.8 & \\
\hline \multirow{2}{*}{3} & \multicolumn{2}{|l|}{99.9} & \multicolumn{2}{|l|}{144} & \multicolumn{2}{|l|}{245} & \multicolumn{2}{|l|}{22} & \multicolumn{2}{|l|}{488.9} & \multirow{2}{*}{8.4} \\
\hline & 39 & 60.9 & 57 & 87 & 145 & 100 & - & 22 & 241 & 247.9 & \\
\hline \multirow{2}{*}{4} & \multicolumn{2}{|l|}{90.5} & \multicolumn{2}{|l|}{162} & \multicolumn{2}{|l|}{275} & \multicolumn{2}{|l|}{17} & \multicolumn{2}{|l|}{527.5} & \\
\hline & 35 & 55.5 & 60 & 102 & 155 & 120 & - & 17 & 250 & 277.5 & 9.0 \\
\hline 5 & 122.7 & & 157 & & 484 & & 22 & & 763.7 & & \\
\hline$\partial$ & 62 & 60.7 & 72 & 85 & 305 & 179 & - & 22 & 439 & 324.7 & .0 \\
\hline & 99.2 & & 175 & & 282 & & 29 & & 556.2 & & \\
\hline 0 & 40 & 59.2 & 66 & 109 & 165 & 117 & - & 29 & 271 & 285.2 & 8.02 \\
\hline 17 & 109.4 & & 186 & & 305 & & 21 & & 600.4 & & \\
\hline I & 45 & 64.4 & 87 & 99 & 170 & 135 & - & 21 & 302 & 298.4 & 9.0 \\
\hline Ave- & 103.7 & & 164 & & 322.29 & & 22.85 & & 590.04 & & \\
\hline rage & 44.57 & 59.19 & 67.71 & 96.29 & 187.14 & 135.14 & - & 22.85 & 299.42 & 290.61 & J \\
\hline
\end{tabular}

The scores for verbal creativity of the Estonian trainee Technology teachers in the final year of studies were higher than the scores for non-verbal creativity only by 3 percent. The informants possessing the highest (9.0) (informants No. 4 and 7) and the lowest (7.6) (informants No. 1 and 2) average grades in the group demonstrated very diverse scores for creative expression (Table 4). The data of this research enables a conclusion that there was no significant relation between the informants' academic achievements and their scores for creative expression in the Estonian group of informants. Moreover, the research did not reveal a significant difference between the scores for verbal and non-verbal creative expression (Table 4). Nevertheless, special attention should be paid to the exceptional creativity of the informant No. 5 and his age. The oldest informant (41 years old) (Table 1) revealed the highest scores for verbal creative fluency (62), verbal and non-verbal originality (305 and 179 respectively), general verbal and non-verbal creativity (439 and 324.7 respectively) and the lowest score for nonverbal fluency (85). Such data show that creative expression is clearly related to a person's individual life experience which can rarely be assessed by grades or any other factors. In other words, everyday life develops creativity, while creativity creates life.

The creativity of the Baltic trainee Technology teachers in their final years of study as a precondition for their readiness to educate the $21^{\text {st }}$ century learners. The average grade for academic achievements of the Baltic trainee technology teachers in their final years of study is higher than 80 percent 
(8 points): the Lithuanian informants had 8.25 , the Latvian informants -8.99 , the Estonian informants -8.23 (Tables 1, 2, 3, 4). Higher than average academic achievements demonstrate not only the knowledge acquired during educational studies, but also higher than average skills and accumulated individual experience which can be creatively applied in practical pedagogical activity as well as in dealing with the issues of the organization of the educational process (Scott, 2007; Hong et al., 2008; Bradley, 2011; Urhahne, 2011). Considering the fact that the learners' achievements mostly depend on the teacher's preparation (Arias, Scafildi, 2009), the preparation of the Baltic trainee Technology teachers in their final years of study creates the preconditions for their learners to reach for their independently raised goals in a psychologically safe environment which promotes their creativity.

There was no significant relation between the Baltic informants' academic achievements and their scores for creative expression determined. However, the case of the Estonian informant (informant No. 5) (Table 4) denies the refutation of the significance of individual life experience and its influence upon creative expression. At school lessons of home economics are oriented at learners' everyday life, their household duties. Hence, it can be assumed that the individual experience that is accumulated in Technology classes cannot be merely applied practically, but also affects their creativity which will be of use not only when solving different routine problems or for self-expression, but also for answering the demands of the labor market and adjusting themselves to the unpredictably changing conditions (Dalin et al., 1999; Hong et al., 2008; Urhahne, 2011).

There was no significant difference between the verbal and non-verbal creative expression of the Lithuanian, Latvian and Estonian informants. It shows equal abilities of the informants to process, analyze, synthesize, apply and adapt both verbal written and visual information. This makes it possible to conceive complex solutions to the situations (Dalin et al., 1999; Bradley, 2011). The results of the research are also significant in the context of the peculiarity of the subject of Technologies. In classes of home economics there merge the creative and productive processes which are based on the practical application of all the other educational subjects. The ability of the Technology teacher to transform verbal information into visual and vice versa is important and significant for the development of the future participant of the labor market of the $21^{\text {st }}$ century who will create the social and economic welfare. Relating the review of literature and the data of the qualitative research, it can be predicted that a creative teacher of Technologies in the Baltic States can be an indicator of a successful and appealing school of the beginning of the $21^{\text {st }}$ century. 


\section{Conclusions}

The analysis of the qualitative research data revealed that the Baltic trainee Technology teachers in their final years of study, irrespective of the average grade for their academic achievements, demonstrated all the target features of creative expression - creative fluency, flexibility, originality and elaboration. Even though the Lithuanian informants got the scores for non-verbal creativity that were higher by 7 percent than those of the other two groups and the Estonian informants got the scores for verbal creativity that were higher by 3 percent than those of the other groups, there was no significant difference between the verbal and non-verbal creativity of the informants. The Baltic trainee Technology teachers are able to analyze and synthesize both verbal written and visual information. Such abilities expand the limits of the students' possibilities. The analysis of the research data makes it possible to state that of great significance for creative expression is individual life experience since it prompts creative amplitude, originality and general creativity, yet it does not guarantee creative flexibility.

The academic achievements of the Baltic trainee Technology teachers in their final years of study are higher than average (more than 80 percent). This enables the trainee teachers to creatively apply the accumulated individual experience, knowledge and skills in practical pedagogical activity, to flexibly deal with different issues related to the organization of the educational process, to apply innovations and meet the needs of the learners, their parents and the labor market, while learners are enabled to reach for individually raised goals in a psychologically safe environment which promotes creativity. The analysis of the research data makes it possible to state that a person's individual life experience is also significant for creative amplitude and creative expression. The ability of the trainee Technology teachers to transform verbal information into visual and vice versa as well as the peculiarity of technological education enables learners to attain significant experience for the development of their individual creativity. Everyday life develops creativity, and creativity creates life. Relating the review of literature and the qualitative research data, it can be predicted that a creative teacher of Technologies in the Baltic States may become an indicator of a successful and appealing school of the $21^{\text {st }}$ century.

Acknowledgement. Postdoctoral fellowship is being funded by European Union Structural Funds project „Postdoctoral Fellowship Implementation in Lithuania” within the framework of the Measure for Enhancing Mobility of Scholars and Other Researchers and the Promotion of Student Research (VP1-3.1-ŠMM-01) of the Program of Human Resources Development Action Plan. 


\section{SOCIETY. INTEGRATION. EDUCATION. Volume I}

\section{References}

Abreu, M.; Faggian, A.; Comunian, R.; McCann, P. (2012). Life is short, art is long': the persistent wage gap between Bohemian and non-Bohemian graduates. Annals of Regional Science. October 2012, Vol. 49 (2), p. 305-321.

Arias, J. J.; Scafildi, B. (2009). When Does Teacher Licensure Make Sense? B.E. Journal of Economic Analysis \& Policy: Advances in Economic Analysis \& Policy. 2009, Vol. 9 (1), preceding p. 1-45.

Bradley, F. (2012). Creativity: does place matter? London Review of Education. July 2012, Vol. 10, No. 2, p. 145-157.

Girdauskiene, L. (2013). The Key Factors for Creativity Implementation and Knowledge Creation in An Organization: The Structural Approach. Economics\& Management. Vol. $18(1)$, p. 176-182.

Gong, Y.; Cheung, S. Y.; Wang, M.; Huang J.C. (2012). Unfolding the Proactive Process for Creativity: Integration of the Employee Proactivity, Information Exchange, and Psychological Safety Perspectives. Journal of Management. Vol. 38 (5), p. 1611-1633.

Haifeng, Q. (2010). Talent, creativity and regional economicperformance: the case of China. Annals of Regional Science. August 2010, Vol. 45 (1), p133-156.

Hong, J. C.; Horng, J. S.; Lin, C. L.; ChanLin, (2008). Competency disparity between preservice teacher education and in-service teaching requirements in Taiwan. International Journal of Educational Development. January 2008, Vol. 28 (1), p. 4-20.

Jieun, P.; Sujin, L.; Eun, J. J.; Kaist, S. (2010). The Influence of Temporal Fit/Nonfit on Creativity in the Leader-Subordinate Context: The Moderating Role of Task Enjoyment versus Performance Concern. Seoul Journal of Business. December 2010, Vol. 16 (2), p. 143-171.

Kim, K. H. (2006). Is Creativity Unidimensional or Multidimensional? Analyses of the Torrance Tests of Creative Thinking. Creativity Research Journal, 18 (3), p. 251-259.

LR švietimo įstatymas (2011/05/26). Vilnius, Sapnu sala, Švietimo ir mokslo ministerijos Švietimo aprüpinimo centras(translation: Law on Education of the Republic of (05/26/2011). Vilnius: Island of Dreams, the Education Supply Center of the Ministry of Education).

Marrocu, E.; Paci, R. (2013). Regional Development and Creativity. International Regional Science Review. July 2013, Vol. 36 (3), p. 354-391.

Miller, A. H.; Imrie, B. W.; Cox, K. (2014). Student Assessment in Higher Education - A Handbook for Assessing Performance. Routledge, London, New York, p. 288.

Morgan, M. (2004). From production line to drama school: highereducation for the future of tourism. International Journal of Contemporary Hospitality Management. Vol. 16 (2), p. 91-99.

Papert, S. (1993). Mindstorms: Children, computers and powerful ideas. Basic Books, New York, p. 252.

Papert, S.; Harel, I. (1991). Constructionism. Ablex Publishing, New York, p. 518.

Patton, M. Q. (2002). Qualitative research \& evaluation methods. Thousand Oaks (Calif.) [etc.], Sage Publications, p. 598.

Pradinio ir pagrindinio ugdymo bendrosios programos (Technologijos) (2008). LR Švietimo ir mokslo ministerija, Vilnius. (translation:Lithuanian General Education Programmes for Technologies(2008). LR Ministry of Education, Vilnius. [online] [19.12.2014]. Available

$<$ http://portalas.emokykla.lt/bup/Puslapiai/pagrindinis_ugdymas_bendras.aspx $>$;

$<$ http://portalas.emokykla.lt/bup/Documents/Pradinis\%20ir\%20pagrindinis\%20ugdyma s/Technologijos.pdf. 
Rego, A.; Junior, D. R.; Cunha, M. P.; Stalbaum, G.; Neves, P. (2014). Store creativity mediating the relationship between affective tone and performance. Managing Service Quality. Vol. 24 (1), p. 63-85.

Scott, G. A. (2007) Teacher Quality: Approaches, Implementation, and Evaluation of Key Federal Efforts: GAO-07-861T. GAO Reports.No. 5 (17), p. 1-17.

Statauskienè, L. (2003). Technologinio ugdymo paradigmos erdvė pasaulyje ir Lietuvoje. Pedagogika(translation: Space of Technology Education Paradigm in the World and in Lithuania, Pedagogy), Vol. 66, p. 15-23.

Statauskienè, L. (2005). Technologinio ugdymo didaktiniu komponentu ir ugdymo proceso dalyviu santykio harmonizavimas. Daktaro disertacija. (translation: The harmonization of the connection between didactic components of technology education and participants of educational process. Doctoral Dissertation), Vytauto Didžiojo universiteto leidykla, Kaunas, p. 182.

Torrance, E. P. (1995).Insights About Creativity: Questioned, Rejected, Ridiculed, Ignored. Educational Psychology Review, 7 (3), p. 313-322.

Urhahne, D. (2011). Teachers Judgments of Elementary Students' Ability, Creativity and Task Commitment. Talent Development \& Excellence. Vol. 3 (2), p. 229-237.

Žygaitienè, B.; Česnavičienè, J.; Švelnienè, D.; Vaivadienè, E.; Numgaudienè, A.; Pošiūnaitè. K. (2014). Technologinis ugdymas Lietuvos bendrojo ugdymo mokyklose: mokslo studija. Vilnius: Lietuvos edukologijos universiteto leidykla (translation: Technology Education in General Education Schools in Lithuania: Science Study. Vilnius: Publishing House of Lithuanian University of Educational Sciences), p. 90. 